Article Type: Research Paper

\title{
The Relationship Between Corporate Governance and Integrated Reporting
}

\author{
Hayyin Agustina Mawardani ${ }^{1}$ and Iman Harymawan ${ }^{2 *}$
}

\begin{abstract}
:
Research aims: The objective of this research is to investigate the level of integrated reporting information disclosure in the annual reports of non-financial public companies listed on the Indonesia Stock Exchange (IDX) from 2017 to 2018 and its relationship with corporate governance, as measured by the independent board, the board size, board gender diversity, and types of the external audit firm, both corporates audited by Big-4 accounting public firm or non-Big-4 accounting public firm.

Design/Methodology/Approach: In this research, the authors utilized a total of 936 observations. The analysis used in this research was the Ordinary Least Square (OLS) Regression.

Research findings: This research showed that corporations with a higher number of independent board members and a bigger board size disclosed a higher level of integrated reporting information. However, the authors did not find a significant correlation between board gender diversity and audit firm types on the level of integrated reporting information disclosure.

Theoretical contribution/Originality: This research contributes to adding to the literature on integrated reporting disclosure theory.

Practitioner/Policy implication: Hopefully, these findings can give the policymaker a comprehensive picture of the relationship between corporate governance and integrated reporting disclosure.

Research limitation/Implication: This paper's limitation is that the measurement of integrated reporting disclosure was conducted using content analysis by word count carried out manually, which might contain the authors' subjectivity.

Keywords: Integrated Reporting; Corporate Governance; Emerging Country
\end{abstract}

\begin{abstract}
AFFILIATION:
1,2 Department of Accounting, Faculty of Economics and Business, Universitas Airlangga, East Java, Indonesia
\end{abstract}

\section{*CORRESPONDENCE:}

harymawan.iman@feb.unair.ac.id

THIS ARTICLE IS AVALILABLE IN:

http://journal.umy.ac.id/index.php/ai

DOI: 10.18196/jai.v22i1.9694

\section{CITATION:}

Mawardani, H. A. \& Harymawan, I. (2021). The Relationship Between Corporate Governance and Integrated Reporting. Journal of Accounting and Investment, 22(1), 51-79.

\section{ARTICLE HISTORY}

Received:

31 Aug 2020

Revised:

02 Oct 2020

15 Nov 2020

Accepted:

25 Nov 2020

\section{Introduction}

Reporting is one way to provide information to stakeholders. Currently, there are many types of reporting that exists in Indonesia. Also, public companies listed on the Indonesia Stock Exchange (IDX) are required by the Financial Services Authority (OJK) to publish three reports: Annual Report, Sustainability Report, and Financial Report. Information obtained from the Annual Report is mainly about summarizing critical financial data, stock information, company profile, good corporate governance, and corporate social responsibility (POJK No. 29/POJK.04/2016). 
Usually, the Annual report is attached to the company's Financial Report/Statement, which mostly contains information about the comparison of the fiscal year and prior year's financial position statement, comprehensive income statement, changes in equity statement, cash flow statement, and notes to financial statements (Keputusan Ketua Bapepam [Decree of the Chairman of the Capital Market and Financial Institution Supervisory Agency]-LK No: Kep-347/BL/2012).

Meanwhile, the Sustainability Report in Indonesia contains information about how the financial services support creating sustainable economic growth by aligning economic, social, and environmental interests (POJK No. 51/POJK.03/2017). As the authors can conclude, these three reports are all mostly about financial information. This information is provided to fulfil decision-makers' necessities, such as investors, creditors, auditors, management, and government. Corporate disclosure has been changing differently in the past year. Terms such as Responsibility, Corporate Reporting, Integrated Reporting, and Corporate Governance have become essential over the past years in the business world (Roxana-loana \& Petru, 2017).

Nowadays, the corporation's perspective is broader due to globalization and nonfinancial regulation growth (Suttipun \& Bomlai, 2019). Corporations have realized that they have to take responsibility after the last global financial crisis, accounting scandals, and the increased environmental disasters that made the stakeholders lose their trust in traditional reporting (Roxana-loana \& Petru, 2017). The traditional reporting presents the financial and non-financial reports separately but fails to establish a connection. It actually can lead to confusion among corporate stakeholders. Other than that, traditional reporting mostly reflects the limited historical performance, and it is not concerned with the crucial targets or risks in the future. Therefore, it fails to support the decision-making process (Krzus, 2011; Suttipun \& Bomlai, 2019).

In reality, investors require trustful integrated information connected to the corporate's business model, value creation process, and risk management (Sofian \& Dumitru, 2017). However, disclosing the integrated financial and non-financial information will be hard if there are no companies' reporting standards. Due to the stakeholders' enormous demands, there was an urge to standardize integrated reporting. Therefore, the International Integrated Reporting Committee (IIRC) published the International Integrated Reporting Framework (IIRF), a conceptual framework of integrated reporting, in 2013.

According to International Integrated Reporting Committee (IIRC), an integrated report is a concise communication of how an organization's strategy, governance, performance, and prospects in the context of its external environment lead to value creation in the short-term, medium-term, and long-term (IIRC, 2013). Integrated report (IR) involves combining financial and non-financial reports into one single report, and it has a higher quality of information for stakeholders. Thus, it helps the company better understand the stakeholders' expectations to enhance the decision-making process (Eccles \& Krzus, 2010). Based on the prior literature, it was discovered that integrated reporting had a positive association with firm valuation. Integrated reporting brings 
more benefits to enhance information quality, and its benefits exceed its cost (Lee \& Yeo, 2016).

The benefits of integrated reporting occur both internally and externally, in which, for the internal benefit, integrated reporting can ensure a better understanding of value creation (Burke \& Clark, 2016). Besides, integrated reporting's external benefit is to maintain the long-term value and relationship with stakeholders (Barnabè, Giorgino, \& Kunc, 2019). However, this reporting category is still voluntary, and it is still in the early stage of adoption in some emerging countries. Meanwhile, companies in the Asian developed countries, such as Japan (Ito \& lijima, 2017) and Singapore (Doni, Larsen, Bianchi Martini, \& Corvino, 2019) have voluntarily adopted integrated reporting to report their performance using one single report. In comparison, another country has implemented integrated reporting as its mandatory report, which is public companies listed in Johannesburg Stock Exchange (JSE) in South Africa (Du Toit, Van Zyl, \& Schütte, 2017).

A previous study in Thailand examined the association of corporate governance and the integrated reporting level, where the specification of corporate governance consisted of ownership structure, the board size, composition of an independent board, and CSR awards (Stuttipun \& Bomlai, 2019). The study conducted with the early adoption of integrated reporting and the degree of sustainability reporting in Thailand remains unclear. The results revealed a positive association between institutional-owned firms, the board size, and companies that received CSR awards with an integrated reporting level. However, the number of samples used was relatively low compared to Indonesia data, even though it involved financial companies. It implied that the number of Thailand companies adopting integrated reporting might be lower than in Indonesia.

While in this study, the authors examined the relationship of corporate governance as measured by the independent board, the board size, board gender diversity, and types of the external audit firm with the level of integrated reporting information disclosure. As mentioned earlier, regarding the countries that have already implemented integrated reporting voluntarily, this study is specified to examine the integrated reporting data with emerging countries' settings in Asia, such as Indonesia. This topic is still classified as a current issue and interesting because there is still a lack of empirical studies on this subject since the integrated report is not mandatory in Indonesia (De Villiers, Rinaldi, \& Unerman, 2014). Interestingly, Indonesian public listed companies have already published Annual Reports that combine both financial and non-financial information. It is appealing to analyze whether the Annual Reports of Indonesian public listed companies have already disclosed what is obligated by the integrated reporting components.

This study used regression analysis to determine the relationship between corporate governance and integrated reporting. For analysis, the authors constructed the keywords based on major content elements of integrated reporting from the International Integrated Reporting Committee (IIRC) framework. Furthermore, the authors conducted the word count methods from keywords, which was later 
constructed as an analysis unit. Besides, the authors also did the content analysis to measure the level of integrated report (IR) information disclosure. This study employed data from an emerging country, such as Indonesia. Therefore, the authors utilized the annual report listed on IDX with the period of 2017 to 2018.

According to the results, the authors found that only independent board member composition and board size had a significant positive relationship with the level of integrated reporting information disclosure. Meanwhile, board gender diversity and types of external audit firms did not significantly correlate with the level of integrated reporting disclosure.

This research is necessary and essential because the results will deepen and broaden knowledge regarding the relationship between corporate governance and integrated reporting. Corporate governance is one of the primary determinants of integrated report disclosure since the management profoundly influences annual report disclosure. Not only that, based on prior literature, integrated reporting is essential to maintain the long-term value and relationship with stakeholders (Barnabè et al. 2019).

This research aims to investigate the level of integrated reporting information disclosure in the annual reports of the non-financial public, especially in Indonesia, an emerging country that is still adopting integrated reporting voluntarily. Since most of the prior literature has examined the integrated reporting in developed countries adopting it as mandatory disclosure, this study specifically assessed the relationship between board characteristics (independent board composition, board size, and board gender diversity) and auditor characteristic (Big-4 or a non-Big-4 audit firm) with the integrated reporting disclosure.

This research has some contributions. The first contribution is adding to the integrated reporting literature by determining which corporate governance indicators influence the integrated reporting disclosure. The second contribution is addressed to the policymaker, the Financial Service Authority (OJK). Expectantly, the research findings provide the policymaker a comprehensive picture of the relationship between corporate governance and integrated reporting disclosure, especially in the public companies listed on the Indonesia Stock Exchange (IDX) in 2017-2018.

\section{Literature Review and Hypotheses Development}

In this research, legitimacy theory was used to investigate the extent and level of integrated reporting in the annual reports of the Indonesian Stock Exchange (IDX) listed companies during 2017-2018. Legitimacy theories are the most used theoretical explanations for the voluntary report, such as the integrated report (Emeseh \& Songi, 2014).

Society demands not only financial information but also non-financial information. According to Suchman (1995), legitimacy is a generalized assumption or perception that 
an entity's actions are appropriate, proper, or desirable within some socially constructed system of definitions, values, beliefs, and norms (Suchman, 1995). Legitimacy theory supports understanding the entities' behavior in applying, establishing, and communicating their social responsibility policies (Zyznarska-Dworczak, 2018).

This theory believes that entities could influence the society in which they operate (Zyznarska-Dworczak, 2018). Hence, a corporation as a part of society must fulfil societal expectations; if not, they have to pay penalties (Gray, Kouhy, \& Lavers, 1995). Legitimacy theory suggests that an entity will act carefully to ensure that its operations, performances, and activities can be accepted by society (Nazli Nik Ahmad \& Sulaiman, 2004).

The second theory employed in this research was the Agency Theory. Agency theory is concerned with the relationship between principals and agents, where principals want to maximize the firm's value, while agents want to maximize profitability. According to Jensen and Meckling (1976), companies' problems occur when stakeholders and management do not have the same incentives, and stakeholders cannot to monitor the management behavior (Jensen \& Meckling, 1976). Eisenhardt (1989) stated that agency theory is concerned with finding a solution to two problems found in agency relationships. The first agency problem is the problem that occurs when the targets or desires of the agent and principal different from each other, and it is not easy, or it costs much money for the principal to verify what the agent is doing and whether the agent has behaved appropriately (Eisenhardt, 1989).

According to Hill and Jones (1992), agency theory focuses on the interest divergence between stockholders and managers (Hill \& Jones, 1992). This interest divergence may reduce firm value and increase agency costs. Since the principal cannot inspect agents' way of behaving, they "rely on imperfect surrogate measures, which can lead the agent to displace his behavior toward the surrogates to appear to be behaving well" (Mitnick, 1992). Therefore, agency costs increase because agents focus and concentrate their efforts on incorrect things (Shapiro, 2005).

To decrease agency costs, the corporation has to be concerned about issuing information in more significant volumes (Huang \& Zhang, 2011). Also, more information disclosure lessens the information asymmetry problem (Suttipun \& Bomlai, 2019).

Cerbioni and Parbonetti (2007) stated that agency problems could be prevented by adopting the integrated reporting (IR) because it provides the owners a means to gain more comprehensive information about the corporation, improve accountability, and increase management transparency (Cerbioni \& Parbonetti, 2007).

Following those theories, the corporation must increase the amount of financial information and non-financial information in their reporting to meet society's desire and reduce information asymmetry. In other words, both financial and non-financial information is equally crucial for the decision-making process. In the integrated report, 
financial and non-financial information are connected and illustrated in one single report. Hopefully, this integrated report will fulfil societal expectations.

The International Integrated Reporting Committee (IIRC) described the eight contents in their International Integrated Reporting Framework (IIRF) that must be included in the integrated report (IIRC, 2013). The first one is the organizational overview and external environment content that answer questions about what corporate does and what fields the corporate operates. This content can be seen from the corporate's vision and mission, changes in quantitative information such as the employees' number, total revenue, and the number of countries where the corporate operates.

The second is governance content, which answers questions about how the corporate governance structure supports its ability to create value in the short-term, mediumterm, and long-term. This content requires information like organizational leadership structures, including their expertise, skills, diversity, and how incentives and remuneration affect value creation.

The third is business model content, which answers questions about what kind of business model implemented in the corporations, including six capitals (financial capital, manufactured capital, intellectual capital, human capital, social and relationship capital, and natural capital) as their inputs, then include corporation's business activities, corporation's outputs, and corporation's outcomes.

The fourth is risks and opportunities content, answering questions about what risks and opportunities affect the corporation's ability to create short-term, medium-term, and long-term value and how organizations deal with corporate. The fifth is strategy and resource allocation to answer questions about where the corporations want to go and how they could get there.

The sixth is performance content to answer questions concerning how well the corporation achieved its strategic objectives for the year and the corporation outcomes that affect the corporate capitals. The seventh content is outlook, which answers questions about what uncertainty and challenges corporate may face in implementing their strategy and the potential implications for the future performance and business model. The information needed for this content is an analysis of quantitative and qualitative changes that occur from time to time.

Previous Research

Based on the previous study from Pavlopoulus, Magnis, and latridis (2017), their findings showed that the quality of integrated report disclosure was positively associated with corporate governance variables. They found that a larger number of non-executive and independent board members would have a higher quality of integrated report disclosure (Pavlopoulos et al., 2017).

Additionally, according to research by Pavlopoulus, Magnis, and latridis (2019), they uncovered that there was a positive relationship between corporate performance and 
the integrated report disclosure quality level. They also mentioned that corporate with a higher level of integrated report disclosure quality tended to disclose an accounting information summary relevance, such as the book value of earnings and equity with higher value (Pavlopoulos et al., 2019).

The research findings by Ghani, Jamal, Puspitasari, and Gunardi (2018) showed that even though the integrated reporting disclosure level among the real property firms in Malaysia has grown from time to time, integrating reporting levels was still low. Their research also found that liquidity, returns on asset (ROA), returns on equity (ROE), and leverage had an insignificant relationship with the integrated reporting disclosure level. They mentioned that audit firm size and corporation size had a significant relationship with the integrated reporting disclosure level (Ghani et al. 2018).

Another study established by Kılıç and Kuzey in 2018 revealed no effect produced by board composition and board size on forward-looking disclosure. Nevertheless, their research mentioned that firm size and board gender diversity had a significant positive relationship with the qualitative and quantitative forward-looking disclosure. Furthermore, their study also showed that leverage was negatively associated with forward-looking qualitative information (Kılıç \& Kuzey, 2018b).

Research from Suttipun and Bomlai (2019) discovered a significant positive correlation among the corporations that received CSR awards, board size, institution-owned corporations, and the integrated reporting disclosure level. Nonetheless, their research mentioned an insignificant relationship between the integrated reporting disclosure level and the CEO duality, independent board member composition, government-owned corporations, and family-owned firms (Suttipun \& Bomlai, 2019).

Another study conducted by Falatifah and Hermawan in 2018 found that the influence of both the audit committee and board of directors' effectiveness was still insignificant. Their study findings proved that the audit committee's effectiveness and the board of directors did not impact integrated report disclosure. Even so, Falatifah and Hermawan exposed that integrated report disclosures could affect lowering equity costs (Falatifah \& Hermawan, 2018).

Shanti, Tjahjadi and Narsa also researched this topic in 2018. They later uncovered that this research's results approved that corporations with more immense leverage and size would have a higher integrated reporting information disclosure level. The other findings revealed that companies that made integrated reports tended to present a higher quality of earnings. Thus, there was a significant positive relationship between integrated reporting and earnings quality (Shanti et al., 2018).

The board of directors is one of the most critical internal control mechanisms because it is chosen by the shareholders to make decisions. To reduce agency costs, boards usually include some independent directors, a professional with neither ownership of the corporation, management role, nor business (Patelli \& Prencipe, 2007). According to Fama and Jensen (1983), the appearance of more independent members on the board 
of directors makes that board of directors more beneficial, with the corporation having to disclose more information (Fama \& Jensen, 1983).

From the previous research conducted by Ho and Wong (2001), they found a positive relationship between the independent member proportion of the board of directors and corporate responsibility reporting in the listed companies' annual reports in Hong Kong (Ho \& Wong, 2001). Patelli and Prencipe's (2007) study also discovered a positive mutual relationship between the independent directors' proportion on the board of directors and the volume of voluntary information disclosure in the non-financial listed companies' annual reports in Italy (Patelli \& Prencipe, 2007). Research from GarciaMeca and Sanchez-Ballesta (2010) showed a positive correlation between board independence and voluntary disclosure, but it only occurred in countries with high investor protection rights (Garcia-Meca \& Sanchez-Ballesta, 2010).

Nevertheless, prior research from Falatifah and Hermawan (2018) uncovered that the effectiveness of the board of directors did not affect integrated reporting (IR) disclosure in 20 countries for firms listed on the International Integrated Reporting Council (IIRC) network database during the period 2015-2017 (Falatifah \& Hermawan, 2018). A study from Suttipun and Bomlai (2019) also found no significant mutual relationship between integrated reporting level and the proportion of independent members of the board of directors in annual reports of companies listed in the Stock Exchange of Thailand from 2012 through 2015 (Suttipun \& Bomlai, 2019). Besides, research from Kılıç and Kuzey (2018) exposed that there was no significant impact created by the board composition on forward-looking disclosures in integrated reporting (IR) (Kıllı̧ \& Kuzey, 2018b). However, this research hypothesized that:

$\boldsymbol{H}_{1}$ : There is a positive relationship between the board independence and level of integrated report (IR) content disclosure.

Board size in Indonesian corporations consists of a board of commissioners (BOC) and a board of directors (BOD). Board size is believed to be one of the major board effectiveness determinants (Amran, Lee, \& Devi, 2014). Larger boards may have bigger complexity and diversity, affecting voluntary information disclosure and increasing the forward-looking disclosure (Elzahar \& Hussainey, 2012).

Research conducted by Suttipun and Bomlai (2019) revealed that publicly listed companies with larger board sizes in Thailand during 2012-2015 disclosed a higher level of integrated reporting information disclosure (Suttipun \& Bomlai, 2019). Meanwhile, research conducted by Kılıç and Kuzey found that there was no correlation between board size and forward-looking disclosures (Kılıç \& Kuzey, 2018b). Even so, the authors hypothesized that:

$\mathrm{H}_{2}$ : There is a positive relationship between the board size and level of integrated report (IR) content disclosure. 
A study about gender diversity mentioned that diversity might give an advantage to the decision-making process since board members with different backgrounds may have various dispersed opinions (Alvarez \& McCaffery, 2000). Other prior studies also stated that board gender diversity impacted firm decisions, and female board members tended to have a different point of view and ask for dissimilar information than the male board members (Krishnan \& Parsons, 2008; Srinidhi, Gul, \& Tsui, 2011; Sun, Liu, \& Lan, 2011).

The prior study from Nalikka (2019) found that the female board members' composition did not correlate with voluntary information disclosure in corporations' annual reports (Nalikka, 2009). Meanwhile, Aribi, Alqatamin, and Arun discovered that board gender diversity positively impacted the level of forward-looking information disclosure (Aribi et al. 2018). Thus, this study hypothesized that:

$\boldsymbol{H}_{3}$ : There is a positive relationship between the board gender diversity and level of integrated report (IR) content disclosure.

According to Ghani et al. (2018), large audit firms are commonly concerned with their image and reputation as they are more eager to relate with corporations that disclose more information in their annual reports. Moreover, large audit firms indeed have more experience dealing with various corporations from different cultures and regions. Other than that, smaller audit firms do not have the power to influence their clients, but smaller audit firms try to meet clients' needs to remain as auditors in the corporations (Ghani et al., 2018).

Audit firms in Indonesia are divided into two. The first group is Big-4 audit firms: Deloitte, PricewaterhouseCoopers (PwC), Ernst and Young (EY), and KPMG. The second group is non-Big-4 audit firms.

The corporations that use one of the Big 4 audit firms as external auditors are expected to disclose more information in their annual reports. Since Big-4 audit firms perform higher quality audits, they may encourage audited corporations to disclose greater amounts of information in the corporations' published annual reports (Hossain, Tan, \& Adams, 1994; Inchausti, 1997; Owusu-Ansah, 1998). It indicates that the voluntary information disclosure level in companies audited by Big- 4 audit firms is more likely to be higher (Hossain, Perera, \& Rahman, 1995).

A study from Barako, Hancock, and Izan (2006) showed that the type of external audit firms did not have a remarkable impact on the level of voluntary information disclosure in Kenya listed companies (Barako et al. 2006). Research from Mohammad Hossain et al. (1995) also revealed that the type of auditor had no significant mutual relationship with the extent of voluntary information disclosure (Hossain et al., 1995). However, the study from Ghani et al. (2018) found that audit firms had a significant influence on the level of integrated reporting practices and voluntary disclosure in Malaysian real property companies (Ghani et al., 2018). Therefore, this research hypothesized that: 
$\boldsymbol{H}_{4}$ : There is a positive relationship between the company being audited by a Big-4 audit and the level of integrated report (IR) content disclosure.

\section{Research Method}

This paper utilized the archival research method. The archival research method involves a study of historical data. It relies on looking at past data sets or records. The data utilized in this research was a quantitative approach because it was easy to measure. The data were collected from annual reports and financial reports of the non-financial public listed companies in Indonesia Stock Exchange (IDX) during 2017-2018. The annual report and the financial reports could be obtained from Indonesia Stock Exchange official website (www.idx.co.id) and the companies' official website. The reports used in this research were mostly in the English language, but for companies that did not publish the reports' English version, the authors used the Indonesian version. For the supporting variables, namely control variables: firm size, liquidity, leverage, and returns on assets, the data were accessed from ORBIS (www.orbis.bvdinfo.com), a web page that provides financial data of corporations in the world.

The population used in this research was all non-financial corporations within the different industrial sectors listed on the Indonesia Stock Exchange (2017-2018). Therefore, the population used in this research was all corporations but excluded the corporations that included code number 6 Standard Industrial Classification (SIC), a code number for financial firms.

Table 1 Sample Selection

\begin{tabular}{lc}
\hline Description & Total \\
\hline Initial observations & 1,248 observations \\
Excluded: & \\
Firms within Financial \& Real Estate Industry (SIC 6) & 288 observations \\
Firms with missing data: & 24 observations \\
Final observations & 936 observations \\
\hline
\end{tabular}

This study inspected the relationship between corporate governance and the level of integrated reporting information disclosure. The corporate governance was measured by four indicators: the independent board members, the board size, board gender diversity, and types of external audit firms, both the corporates audited by a Big-4 accounting public firm and a non-Big-4 accounting public firm. The level of integrated reporting information disclosure was assessed by content analysis using word count. To inspect the relationship between corporate governance and the level of integrated reporting information disclosure, this paper was helped by some control variables: firm size, leverage, liquidity, and returns on assets (ROA).

This research utilized three variables: the dependent variable, the independent variable, and the control variable. The detail of the variable names is presented in Appendix-A. This study's research design is: 
$I R D=\alpha+b_{1} I N D B O A R D+b_{2}$ BOARDSIZE $+b_{3}$ FEMALE $+b_{4}$ BIG4 $+b_{5}$ FIRMSIZE $+b_{6}$ LEVERAGE $+b_{7} L I Q U I D I T Y+B_{8} R O A+\varepsilon$

This study used the Integrated Reporting information disclosure level dependent variable with seven out of the eight Integrated Reporting (IR) content elements. The authors decided to exclude the 8th content element, the basis of preparation and presentation because this content assessment required heavy judgments to be made by authors; it might be subjective and biased. The authors collected the data by obtaining Annual Reports from corporations' websites and the Indonesian Stock Exchange's (IDX) website.

Integrated Reporting (IR) information disclosure was analyzed by conducting a content analysis of Content Elements from International Integrated Reporting Framework (IIRF) published by the International Integrated Reporting Council (IIRC) (Kılıç \& Kuzey, 2018a; Nakib \& Dey, 2018; Pratama, 2017; Suttipun \& Bomlai, 2019). Content analysis was used to quantify the pattern, the extent, and the integrated reporting information disclosure level.

The authors employed the word count method for the dependent variables to the corporations' annual reports and financial reports as analyzing units since it could be easily classified and required less subjective judgment from the authors (Gamerschlag, Möller, \& Verbeeten, 2011). The guidelines were the disclosure index of 46 items from 7 content elements that had to be disclosed under the International Integrated Reporting Framework (IIRF). From these 46 items, the authors selected a total of 92 keywords. The list of the keywords used is described in Appendix-B on the last page of this paper. The disclosure index used in this study can be described as follows:

$$
I R D=\ln (O R+G V+B M+R O+S R+P F+O L)
$$

Furthermore, the detail of the integrated reporting components disclosure index can be seen in Appendix-C.

The corporate governance indicators consisted of four variables: independent board members (INDBOARD), board size (BOARDSIZE), board gender diversity (FEMALE), and type of the external auditor (BIG4).

Independent board members were measured by calculating the independent members' proportion on board (Ofoegbu, Odoemelam, \& Okafor, 2018). Board size was gauged by calculating the total number of board members (Fasan \& Mio, 2017). Board gender diversity calculated the proportion of female members on board (Nalikka, 2009). The type of the external auditor was assessed as a binary variable or dummy that equal to 1 if the external audit firm auditing the company is one of the Big-4 audit firms (Ernst and Young, PricewaterhouseCoopers, KPMG, or Deloitte) and 0 if the external audit firm auditing the company is non-Big-4 audit firms (Ghani et al., 2018). 


$$
I N D B O A R D=\frac{I N D C O M M+I N D D I R}{B O A R D S I Z E}
$$

Definition:

INDBOARD= Independent board members

INDCOMM = Independent commissioners

INDDIR = Independent directors

BOARDSIZE = Total board size

$$
B O A R D S I Z E=B O C+B O D
$$

Definition:

BOARDSIZE

$B O C$

= Total board size

$B O D$

= Board of commissioners

$=$ Board of directors

$$
F E M A L E=\frac{\text { FEMALEBOARD }}{\text { BOARDSIZE }}
$$

Definition:
FEMALE
$=$ Ratio of female board members
FEMALEBOARD = Number of female members on board

$B O A R D S I Z E=$ Total board size

\section{Result and Discussion}

Table 2 presents a summary of information about the descriptive statistical test results for the data variables used. The table displays the dependent variable of integrated reporting information disclosure (IRD) with the average value of 4.734, the median of 5.995 , the minimum value of 0.000 , and the maximum value of IRD of 7.651 . Meanwhile, the independent variable of INDBOARD had an average value of 0.290 , the median of 0.286 , the minimum value of 0.000 , and the maximum value of 0.714 .

Table 2 Descriptive Statistics

\begin{tabular}{lcccc}
\hline Variable & Mean & Median & Minimum & Maximum \\
\hline IRD & 4.734 & 5.995 & 0.000 & 7.651 \\
INDBOARD & 0.290 & 0.286 & 0.000 & 0.714 \\
BOARDSIZE & 8.310 & 8.000 & 2.000 & 24.000 \\
FEMALE & 0.130 & 0.111 & 0.000 & 1.000 \\
BIG4 & 0.323 & 0.000 & 0.000 & 1.000 \\
FIRMSIZE & 21.471 & 21.432 & 17.501 & 26.308 \\
LEVERAGE & 0.540 & 0.489 & 0.023 & 3.593 \\
LIQUIDITY & 2.687 & 1.416 & 0.055 & 60.582 \\
ROA & 2.127 & 2.555 & -38.930 & 30.650 \\
\hline
\end{tabular}


Table 2 shows that the average value of BOARDSIZE was 8.310 , the median was 8.000 , the minimum value was 2.000 , and the maximum value was 24.000 . While for variable FEMALE, the average value was 0.130 , the median was 0.111 , the minimum value was 0.000 , and the maximum value was 1.000 . Besides, the average value of BIG4 was 0.323 , the median of BIG4 was 0.000 , the minimum value of BIG4 was 0.000 , and the maximum value of BIG4 was 1.000. The integrated reporting disclosure was measured using word count. The results of the integrated reporting disclosure are presented in detail in Appendix-D.

Table 3 exhibits information regarding the correlation between the variables used. It revealed that IRD had a positive correlation with a significant level of $1 \%$ with INDBOARD, BOARDSIZE, and BIG4. Other than that, IRD also negatively correlated with a significant level of $1 \%$ with FEMALE. The table also presents that INDBOARD had a negative correlation with a significant level of $1 \%$ with BOARDSIZE and $5 \%$ with BIG4. Meanwhile, with FEMALE, it showed that there was a negative correlation but no significance to it. It also mentioned that BOARDSIZE negatively correlated with a significant level of $1 \%$ with FEMALE and a positive correlation with a significant level of $1 \%$ with BIG4. The next variable was FEMALE, which negatively correlated with a significant level of $1 \%$ with BIG4.

Table 3 Pearson Correlation

\begin{tabular}{lccccc}
\hline & IRD & INDBOARD & BOARDSIZE & FEMALE & BIG4 \\
\hline IRD & 1.000 & & & \\
INDBOARD & & & & \\
& $0.155^{* * *}$ & 1.000 & & & \\
BOARDSIZE & $(0.000)$ & & & & \\
& $0.281^{* * *}$ & $-0.172^{* * *}$ & 1.000 & & \\
FEMALE & $(0.000)$ & $(0.000)$ & & & \\
& $-0.088^{* * *}$ & -0.043 & $-0.133^{* * *}$ & & \\
BIG4 & $(0.007)$ & $(0.192)$ & $(0.000)$ & & \\
& $0.170^{* * *}$ & $-0.068^{* *}$ & $0.413^{* * *}$ & $-0.132^{* * *}$ & 1.000 \\
FIRMSIZE & $(0.000)$ & $(0.036)$ & $(0.000)$ & $(0.000)$ & \\
& $0.327^{* * *}$ & $-0.084^{* * *}$ & $0.649^{* * *}$ & $-0.180^{* * *}$ & $0.452^{* * *}$ \\
LEVERAGE & $(0.000)$ & $(0.010)$ & $(0.000)$ & $(0.000)$ & $(0.000)$ \\
& $-0.065^{* *}$ & $-0.068^{* *}$ & -0.053 & $-0.070^{* *}$ & $-0.066^{* *}$ \\
LIQUIDITY & $(0.048)$ & $(0.038)$ & $(0.108)$ & $(0.032)$ & $(0.045)$ \\
& $-0.076^{* *}$ & $0.163^{* * *}$ & $-0.111^{* * *}$ & 0.008 & $-0.067^{* *}$ \\
ROA & $(0.020)$ & $(0.000)$ & $(0.001)$ & $(0.811)$ & $(0.040)$ \\
& $0.081^{* *}$ & $-0.087^{* * *}$ & $0.220^{* * *}$ & 0.042 & $0.230^{* * *}$ \\
\hline P-VIUES in Parent & $(0.013)$ & $(0.008)$ & $(0.000)$ & $(0.198)$ & $(0.000)$ \\
\hline
\end{tabular}

p-values in parentheses

${ }^{*} p<0.1, * * p<0.05, * * * p<0.01$

From this brief explanation, it can be seen that there was an early sign that corporate governance and integrated reporting had a strong correlation. When the independent member board and the board size were larger, followed by being audited by one of the Big-4 accounting public firms, the level of integrated reporting disclosure value was also 
higher. Meanwhile, when the female board size was larger, the integrated reporting disclosure level would be lower.

In this study, multiple linear regression was implemented to determine corporate governance's relationship with the level of integrated reporting information disclosure. This study applied the robustness test using cluster-standard error so that the results were more accurate.

Table 4 presents the multiple linear regression results between corporate governance and integrated reporting disclosure (IRD). Corporate governance was measured by using a ratio of independent board members (INDBOARD), total board size (BOARDSIZE), board gender diversity (FEMALE), and types of external audit firms (BIG4).

The first column of the table represents the regression between INDBOARD and IRD. The result uncovered a positive significance at a $1 \%$ level between INDBOARD and IRD with a coefficient value of 4.143. It indicated that corporations with a greater number of independent boards disclosed the highest integrated reporting information. These results supported the first hypothesis, where there was a positive relationship between independent board members and the level of integrated reporting information disclosure.

Table 4 Multiple Linear Regression

\begin{tabular}{|c|c|c|c|c|c|c|}
\hline \multirow[t]{2}{*}{ Variables } & \multirow{2}{*}{$\begin{array}{c}\text { Sign } \\
\text { Predict. }\end{array}$} & \multicolumn{5}{|c|}{ Integrated Reporting Disclosure (IRD) } \\
\hline & & (1) & (2) & (3) & (4) & (5) \\
\hline \multirow[t]{2}{*}{ INDBOARD } & + & $4.143^{* * *}$ & & & & $4.564^{* * *}$ \\
\hline & & $(5.50)$ & & & & $(6.32)$ \\
\hline \multirow[t]{2}{*}{ BOARDSIZE } & + & & $0.099^{* * *}$ & & & $0.126^{* * *}$ \\
\hline & & & (2.69) & & & $(3.40)$ \\
\hline \multirow[t]{2}{*}{ FEMALE } & + & & & -0.644 & & -0.332 \\
\hline & & & & $(-1.07)$ & & $(-0.59)$ \\
\hline \multirow[t]{2}{*}{$B I G 4$} & + & & & & 0.182 & 0.084 \\
\hline & & & & & $(0.92)$ & $(0.41)$ \\
\hline \multirow[t]{2}{*}{ FIRMSIZE } & + & $0.482^{* * *}$ & $0.346^{* * *}$ & $0.458^{* * *}$ & $0.445^{* * *}$ & $0.313^{* * *}$ \\
\hline & & (9.93) & $(5.36)$ & $(9.20)$ & $(7.96)$ & $(4.78)$ \\
\hline \multirow[t]{2}{*}{ LEVERAGE } & - & -0.297 & $-0.394^{*}$ & $-0.388^{*}$ & $-0.378^{*}$ & -0.321 \\
\hline & & $(-1.42)$ & $(-1.90)$ & $(-1.85)$ & $(-1.82)$ & $(-1.53)$ \\
\hline \multirow[t]{2}{*}{ LIQUIDITY } & + & -0.020 & -0.012 & -0.011 & -0.011 & $-0.024^{*}$ \\
\hline & & $(-1.40)$ & $(-0.86)$ & $(-0.78)$ & $(-0.76)$ & $(-1.69)$ \\
\hline \multirow[t]{2}{*}{$R O A$} & + & 0.005 & -0.003 & 0.001 & -0.001 & 0.001 \\
\hline & & $(0.52)$ & $(-0.30)$ & $(0.08)$ & $(-0.11)$ & $(0.12)$ \\
\hline \multirow[t]{2}{*}{ _cons } & ? & $-7.073^{* * *}$ & $-3.691^{* * *}$ & $-5.263^{* * *}$ & $-5.130^{* * *}$ & $4.491^{* * *}$ \\
\hline & & $(-6.36)$ & $(-2.93)$ & $(-4.66)$ & $(-4.17)$ & $(-3.46)$ \\
\hline Year dummies & & included & included & included & included & included \\
\hline Industry dummies & & included & included & included & included & included \\
\hline r2 & & 0.160 & 0.140 & 0.133 & 0.133 & 0.174 \\
\hline$N$ & & 936 & 936 & 936 & 936 & 936 \\
\hline
\end{tabular}

t statistics in parentheses

$* \mathrm{p}<0.1, * * \mathrm{p}<0.05, * * * \mathrm{p}<0.01$ 
For the second column of the table, it showed the regression between BOARDSIZE and IRD. It signified that there was also a positive significant at $1 \%$ level between BOARDSIZE and IRD with a coefficient value of 0.099. It revealed that corporations with larger board sizes disclosed higher integrated reporting information. This result was in line with the second hypothesis, stating a positive relationship between total board size and integrated reporting information disclosure level.

The third column of the table illustrates the regression between FEMALE and IRD. It denoted that there was an insignificant result for board gender diversity with the integrated reporting information disclosure. The result rejected the third hypothesis so that there was a positive relationship between board gender diversity and the level of integrated reporting information disclosure.

The fourth column of the table shows the regression between BIG4 and IRD. It also indicated an insignificant relationship between the type of external audit firms and integrated reporting information disclosure. Thus, this regression results also rejected the fourth hypothesis.

The fifth column of the table presents that the results came up with the same analysis when all variables were combined. Independent board members (INDBOARD) and total board size (BOARDSIZE) still had a significant positive relationship with the level of integrated reporting information disclosure (IRD). Besides, board gender diversity (FEMALE) and type of external audit (BIG4) still had an insignificant relationship with the level of integrated reporting information disclosure (IRD).

For the control variables, FIRMSIZE positively had a significant relationship with IRD, INDBOARD, BOARDSIZE, FEMALE, and BIG4. It is in accordance with prior research that stated the bigger the firm size, the higher the disclosure level of integrated reporting information. Corporations with higher firm size are expected to face a higher level of information asymmetry and expected to interact with more different stakeholders (Ghani et al., 2018; Kılıç \& Kuzey, 2018b).

Meanwhile, for LEVERAGE, it was only negatively and significantly related to BOARDSIZE, FEMALE, and BIG4 at a 10\% significant level. For LIQUIDITY, it was only negatively and significantly related to IRD at a $10 \%$ significant level. It suggested that higher liquidity resulted in a lower level of integrated reporting disclosure. The last control variable was ROA; it showed that ROA had no significant relationship with all variables.

The multiple linear regression showed that 2 out of 4 of the corporate governance measurements, the ratio of an independent board and total board size, had a significant positive relationship with the level of integrated reporting information disclosure. It indicated that the $\mathrm{H} 1$ was accepted, where corporations with more numbers of independent members on board disclosed a higher level of integrated reporting information than the corporations with fewer numbers of independent members on board. According to Jizi, Salama, Dixon, and Stratling (2014), boards with a larger composition of independent members are more effective in controlling and monitoring 
management and more successful in leading management to reach the company's longterm value. Independent members may have a bigger tendency to persuade or motivate the firms to disclose more forward-looking information since they are less aligned with firm management (Michelon \& Parbonetti, 2012). Hence, if the independent members dominate the board, they may have the power to encourage management to disclose a higher level of voluntary information, which in this study emphasizes integrated reporting information disclosure (Wang \& Hussainey, 2013).

Furthermore, this study supported the $\mathrm{H} 2$, where corporations with a larger board size disclosed a higher level of integrated reporting information than the corporations with smaller board size. Based on (Kılıç \& Kuzey, 2018b) research, they affirmed that since board members have a monitoring role, corporations with effective boards can affect management decisions that can improve information disclosures. Therefore, board characteristics may significantly affect corporate disclosure. Larger board size is believed to be an effective governance mechanism, encouraging voluntary and transparent firms' disclosure (Akhtaruddin, Hossain, Hossain, \& Yao, 2009). Large boards could also affect the management's voluntary disclosure decision, so be willing to disclose more forwardlooking information (Elzahar \& Hussainey, 2012; Wang \& Hussainey, 2013).

Meanwhile, for the other two measurements, the board gender diversity and type of external audit firm, there was no significant relationship with the integrated reporting information disclosure level. It signified that $\mathrm{H} 3$, where corporations with more numbers of female members on board disclosed a higher level of integrated reporting information, was rejected. Theoretically, board members with various characteristics can give various ideas and points of view. Gender diversity on boards could give more opinions and perspectives so that boards can discuss more and make a better decision (Barako \& Brown, 2008; Bear, Rahman, \& Post, 2010).

Only 764 out of 1,248 Indonesian firms had female members on board during 20172018 , with a total of 1,364 females. Meanwhile, for the male members, there were 1,234 out of 1,248 firms with male members on board during 2017-2018, with a total of 8,986 males. This amount was 7.2 times higher than the female members. It could be the reason why the influence of board gender diversity was not significant in Indonesia. When only a small proportion of females are elected or appointed to a board, a neutralization or minority invisibility phenomenon can happen (Manita, Bruna, Dang, \& Houanti, 2018). Therefore, with no power, status, and voice, it may reduce the capability to influence the company disclosure. Hence, female members' effect on the level of integrated reporting could be insignificant and even negative.

Furthermore, the $\mathrm{H} 4$, where corporations being audited by Big-4 accounting public firms, disclosed a higher level of integrated reporting information, was rejected. Prior literature has suggested that bigger external audit firms are usually concerned with its reputation as they are more willing to relate with firms that disclose higher information in their reports (Ghani et al., 2018). The regression that has been implemented found that the external audit firm had an insignificant positive relationship with the level of integrated reporting disclosure in firms in Indonesia. 
External auditors appeared to have a small impact on corporations' integrated reporting information disclosure in their annual reports. The small impact of the type of external auditors toward the integrated reporting information disclosure was because of the possibility that external auditors' role was limited due to the boundaries of mandatory information set by the regulators. In short, external auditors generally do not ask or require or mandate their clients to disclose information that exceeds the information required by the accounting standards (Soliman, 2013). Therefore, the integrated reporting information disclosure results among corporations that were audited by Big-4 and non-Big-4 had similar results.

\section{Conclusion}

The traditional annual reports mainly focused only on historical performance rather than future performance. The integrated report is expected to give companies new insights by providing information that can be used for short-term, middle-term, and long-term decision-making. This research examined the relationship between corporate governance and the level of integrated reporting information disclosure of publicly listed companies in the Indonesia Stock Exchange (IDX) for 2017-2018 with a total data of 936 observations.

This paper's findings revealed a positive relationship between board independence and board size with the level of integrated reporting information disclosure. It implied that corporations with more numbers of independent members and larger board sizes disclosed a higher level of integrated reporting information. Meanwhile, there was no significant relationship between board gender and audit firm types with integrated reporting information disclosure level.

This study can enrich the literature on corporate governance and integrated reporting since this research's findings will help integrated reporting disclosure theory and determine which corporate governance indicators influence the integrated reporting disclosure. The second contribution is to the policymaker, which is the Financial Service Authority (OJK). Hopefully, the research findings will give the policymaker a comprehensive picture of the relationship between corporate governance and integrated reporting disclosure, especially in the public companies listed in the Indonesia Stock Exchange (IDX) in 2017-2018.

On the other hand, this study still has a limitation regarding the measurement of integrated reporting disclosure. The content analysis by word count was done manually, which might contain the authors' subjectivity. From this study's results, it is expected that future researchers must be aware of this subjectivity in the research. If possible, they must describe their subjectivity in the study and process every data found carefully and correctly to minimize it. 


\section{Appendix}

Table Appendix-A Variable Definition

\begin{tabular}{|c|c|c|c|}
\hline Variable & Definition & Measurement & Data Source \\
\hline \multicolumn{4}{|c|}{ Dependent Variable } \\
\hline IRD & $\begin{array}{l}\text { Integrated } \\
\text { Reporting } \\
\text { disclosure }\end{array}$ & $\begin{array}{l}\text { The natural } \\
\text { logarithm (In) of } \\
\text { Integrated } \\
\text { Reporting } \\
\text { disclosure from the } \\
\text { content analysis } \\
\text { results of Annual } \\
\text { Reports by word } \\
\text { count }\end{array}$ & $\begin{array}{l}\text { Annual Reports } \\
\text { and Financial } \\
\text { Reports }\end{array}$ \\
\hline \multicolumn{4}{|c|}{ Independent Variable } \\
\hline INDBOARD & $\begin{array}{l}\text { Independent board } \\
\text { members }\end{array}$ & $\begin{array}{l}\text { The proportion of } \\
\text { independent } \\
\text { members on board }\end{array}$ & $\begin{array}{l}\text { Annual Reports } \\
\text { and Financial } \\
\text { Reports }\end{array}$ \\
\hline BOARDSIZE & Board size & $\begin{array}{l}\text { Total number of } \\
\text { board members }\end{array}$ & $\begin{array}{l}\text { Annual Reports } \\
\text { and Financial } \\
\text { Reports }\end{array}$ \\
\hline FEMALE & Board gender & $\begin{array}{l}\text { The proportion of } \\
\text { female members on } \\
\text { board }\end{array}$ & $\begin{array}{l}\text { Annual Reports } \\
\text { and Financial } \\
\text { Reports }\end{array}$ \\
\hline BIG4 & External audit firm & $\begin{array}{l}\text { Coded as } 1 \text { for Big- } 4 \\
\text { audit firms, and } \\
\text { coded as } 0 \text { for non- } \\
\text { Big- } 4 \text { audit firms }\end{array}$ & $\begin{array}{l}\text { Annual Reports } \\
\text { and Financial } \\
\text { Reports }\end{array}$ \\
\hline \multicolumn{4}{|c|}{ Control Variable } \\
\hline FIRMSIZE & Firm size & $\begin{array}{l}\text { The natural } \\
\text { logarithm (In) of } \\
\text { total assets }\end{array}$ & $\begin{array}{l}\text { Annual Reports } \\
\text { and Financial } \\
\text { Reports }\end{array}$ \\
\hline LEVERAGE & Leverage & $\begin{array}{l}\text { The ratio of total } \\
\text { liabilities divided by } \\
\text { total assets }\end{array}$ & $\begin{array}{l}\text { Annual Reports } \\
\text { and Financial } \\
\text { Reports }\end{array}$ \\
\hline LIQUIDITY & Liquidity & $\begin{array}{l}\text { The ratio of current } \\
\text { assets divided by } \\
\text { current liabilities }\end{array}$ & $\begin{array}{l}\text { Annual Reports } \\
\text { and Financial } \\
\text { Reports }\end{array}$ \\
\hline ROA & $\begin{array}{l}\text { Returns on Asset } \\
\text { (ROA) }\end{array}$ & $\begin{array}{l}\text { Net income divided } \\
\text { by average total } \\
\text { asset }\end{array}$ & $\begin{array}{l}\text { Annual Reports } \\
\text { and Financial } \\
\text { Reports }\end{array}$ \\
\hline
\end{tabular}


Mawardani \& Harymawan

The Relationship Between Corporate Governance and Integrated Reporting

Table Appendix-B Integrated Reporting Content Elements Keywords

\begin{tabular}{|c|c|c|c|}
\hline IR Content Elements & Items & Notation & Keywords \\
\hline \multirow{11}{*}{$\begin{array}{l}\text { Organizational } \\
\text { overview and } \\
\text { external } \\
\text { environment } \\
\text { What does the } \\
\text { organization do, and } \\
\text { what are the } \\
\text { circumstances under } \\
\text { which it operates? }\end{array}$} & $\begin{array}{l}\text { Identifies the organization's culture, ethics, and value, ownership and operating structure, } \\
\text { competitive landscape and market positioning, position in the value chain }\end{array}$ & OR-1 & $\begin{array}{l}\text { "culture", "ethics", } \\
\text { "value", "ownership } \\
\text { structure" "operating } \\
\text { structure" }\end{array}$ \\
\hline & $\begin{array}{l}\text { Identifies key quantitative information (e.g., the number of employees, revenue and } \\
\text { number of countries in which the organization operates), highlighting, in particular, } \\
\text { significant changes from prior periods }\end{array}$ & OR-2 & $\begin{array}{l}\text { "total employees" } \\
\text { "financial highlights." }\end{array}$ \\
\hline & Significant factors affecting the external environment and the organization's response & OR-3 & $\begin{array}{l}\text { "external environment" } \\
\text { "response" }\end{array}$ \\
\hline & The legitimate needs and interests of key stakeholders & OR-4 & "stakeholders" \\
\hline & $\begin{array}{l}\text { Macro and microeconomic conditions, such as economic stability, globalization, and industry } \\
\text { trends }\end{array}$ & OR-5 & $\begin{array}{l}\text { "micro", "macro" } \\
\text { "stability", "trends", } \\
\text { "globalization" }\end{array}$ \\
\hline & $\begin{array}{l}\text { Market forces, such as the relative strengths and weaknesses of competitors and customer } \\
\text { demand }\end{array}$ & OR-6 & $\begin{array}{l}\text { "market forces", } \\
\text { "customers" } \\
\text { "competitors" }\end{array}$ \\
\hline & The speed and effect of technological change & OR-7 & "technology," "speed." \\
\hline & $\begin{array}{l}\text { Societal issues, such as population and demographic changes, human rights, health, poverty, } \\
\text { collective values and educational systems }\end{array}$ & OR-8 & "social" \\
\hline & $\begin{array}{l}\text { Environmental challenges, such as climate change, the loss of ecosystems, and resource } \\
\text { shortages as planetary limits are approached }\end{array}$ & OR-9 & "environmental" \\
\hline & The legislative and regulatory environment in which the organization operates & OR-10 & "regulation," "OJK." \\
\hline & $\begin{array}{l}\text { The political environment in countries where the organization operates and other countries } \\
\text { may affect the ability of the organization to implement its strategy }\end{array}$ & OR-11 & "Politic" \\
\hline
\end{tabular}


Mawardani \& Harymawan

The Relationship Between Corporate Governance and Integrated Reporting

Table Appendix-B Integrated Reporting Content Elements Keywords (cont')

\begin{tabular}{|c|c|c|c|}
\hline IR Content Elements & Items & Notation & Keywords \\
\hline \multirow{7}{*}{$\begin{array}{l}\text { Governance } \\
\text { How does the } \\
\text { organization's } \\
\text { governance } \\
\text { structure support } \\
\text { its ability to create } \\
\text { value in the short, } \\
\text { medium and long } \\
\text { term? }\end{array}$} & $\begin{array}{l}\text { The organization's leadership structure, including the skills and diversity (e.g., range of } \\
\text { backgrounds, gender, competence and experience) of those charged with governance and } \\
\text { whether regulatory requirements influence the design of the governance structure }\end{array}$ & GV-1 & $\begin{array}{l}\text { "director" "commissioner" } \\
\text { "audit committee" } \\
\text { "internal audit" "secretary" }\end{array}$ \\
\hline & $\begin{array}{l}\text { Specific processes used to make strategic decisions and to establish and monitor the culture } \\
\text { of the organization, including its attitude to risk and mechanisms for addressing integrity and } \\
\text { ethical issues }\end{array}$ & GV-2 & "decision" "monitor" \\
\hline & $\begin{array}{l}\text { Particular actions those charged with governance have taken to influence and monitor the } \\
\text { strategic direction of the organization and its approach to risk management }\end{array}$ & GV-3 & "actions" \\
\hline & $\begin{array}{l}\text { How the organization's culture, ethics and values are reflected in its use of and effects on the } \\
\text { capitals, including its relationships with key stakeholders }\end{array}$ & GV-4 & "culture" "ethic" "value" \\
\hline & Whether the organization is implementing governance practices that exceed legal requirements & GV-5 & "legal" \\
\hline & The responsibility those charged with governance take for promoting and enabling innovation & GV-6 & "innovation" \\
\hline & $\begin{array}{l}\text { How remuneration and incentives are linked to value creation in the short, medium and long } \\
\text { term, including how they are linked to the organization's use of and effects on the capitals }\end{array}$ & GV-7 & $\begin{array}{l}\text { "remuneration" "incentive" } \\
\text { "value creation" }\end{array}$ \\
\hline \multirow[t]{8}{*}{$\begin{array}{l}\text { Business Model } \\
\text { What is the } \\
\text { organization's } \\
\text { business model? }\end{array}$} & Describe business model input (paragraph 4.14-4.15) & BM-1 & $\begin{array}{l}\text { "capital" "manufactured" } \\
\text { "intellectual capital" } \\
\text { "human capital" "CSR" } \\
\text { "natural" }\end{array}$ \\
\hline & Describe business model Business activities (paragraph 4.16-4.17) & BM-2 & "business model." \\
\hline & Describe Outputs (paragraph 4.18 IIRC) & BM-3 & "output" \\
\hline & Describe Outcomes (paragraphs 4.19-4.20). & BM-4 & "outcome" \\
\hline & An explicit identification of the key elements of the business model & BM-5 & "business model." \\
\hline & $\begin{array}{l}\text { A simple diagram highlighting key elements, supported by a clear explanation of the relevance of } \\
\text { those elements to the organization }\end{array}$ & BM-6 & "-" \\
\hline & A narrative flow that is logical given the particular circumstances of the organization & BM-7 & "-" \\
\hline & $\begin{array}{l}\text { Identification of critical stakeholder and others (e.g., raw material) dependencies and essential } \\
\text { factors affecting the external environment }\end{array}$ & BM-8 & "stakeholder" "supplier." \\
\hline
\end{tabular}


Mawardani \& Harymawan

The Relationship Between Corporate Governance and Integrated Reporting

Table Appendix-B Integrated Reporting Content Elements Keywords (cont')

\begin{tabular}{|c|c|c|c|}
\hline IR Content Elements & Items & Notation & Keywords \\
\hline & $\begin{array}{l}\text { Connection to information covered by other Content Elements, such as strategy, risks and } \\
\text { opportunities, and performance (including KPIs and financial considerations, like cost } \\
\text { containment and revenues) }\end{array}$ & BM-9 & "Key Performance Indicator" \\
\hline \multirow{3}{*}{$\begin{array}{l}\text { Risk and } \\
\text { opportunities } \\
\text { What are the } \\
\text { specific risks and } \\
\text { opportunities that } \\
\text { affect the } \\
\text { organization's ability } \\
\text { to create value over } \\
\text { the short, medium } \\
\text { and long term, and } \\
\text { how is the } \\
\text { organization dealing } \\
\text { with them? }\end{array}$} & $\begin{array}{l}\text { The specific source of risks and opportunities, which can be internal, external or, commonly, a } \\
\text { mix of the two, internal and external risk }\end{array}$ & RO-1 & $\begin{array}{l}\text { "internal risk", "external } \\
\text { risk" }\end{array}$ \\
\hline & $\begin{array}{l}\text { The organization's assessment of the likelihood that the risk or opportunity will come to fruition } \\
\text { and the magnitude of its effect if it does. }\end{array}$ & RO-2 & "risk assessment." \\
\hline & $\begin{array}{l}\text { The specific steps are taken to mitigate or manage key risks or create value from key } \\
\text { opportunities, including identifying the associated strategic objectives, strategies, policies, } \\
\text { targets, and KPIs. }\end{array}$ & RO-3 & "risk management." \\
\hline \multirow{6}{*}{$\begin{array}{l}\text { Strategy and } \\
\text { resource allocation } \\
\text { Where does the } \\
\text { organization want to } \\
\text { go, and how does it } \\
\text { intend to get there? }\end{array}$} & The organization's short, medium and long term strategic objectives & SR-1 & $\begin{array}{l}\text { "strategic objective" / } \\
\text { "strategic intent" }\end{array}$ \\
\hline & The strategies it has in place or intends to implement to achieve those strategic objectives & SR-2 & "strategy" \\
\hline & The resource allocation plans it has to implement its strategy & SR-3 & "resources" \\
\hline & How it will measure achievements and target outcomes for the short, medium and long term & SR-4 & "achievement" "target" \\
\hline & $\begin{array}{l}\text { The linkage between the organization's strategy and resource allocation plans and the } \\
\text { information covered by other Content Elements, including how its strategy and resource } \\
\text { allocation plans }\end{array}$ & SR-5 & "strategy," "resources." \\
\hline & $\begin{array}{l}\text { What differentiates the organization to give it a competitive advantage and enable it to create } \\
\text { value (innovation, intellectual capital, competitive advantage) }\end{array}$ & SR-6 & $\begin{array}{l}\text { "innovation", "intellectual } \\
\text { capital", "competitive } \\
\text { advantage" }\end{array}$ \\
\hline
\end{tabular}


Mawardani \& Harymawan

The Relationship Between Corporate Governance and Integrated Reporting

Table Appendix-B Integrated Reporting Content Elements Keywords (cont')

\begin{tabular}{|c|c|c|c|}
\hline IR Content Elements & Items & Notation & Keywords \\
\hline & $\begin{array}{l}\text { Key features and findings of stakeholder engagement that were used in formulating its strategy } \\
\text { and resource allocation plans }\end{array}$ & SR-7 & "strategy" \\
\hline \multirow{4}{*}{$\begin{array}{l}\text { Performance } \\
\text { To what extent has } \\
\text { the organization } \\
\text { achieved its } \\
\text { strategic objectives } \\
\text { for the period, and } \\
\text { what are its } \\
\text { outcomes in terms } \\
\text { of effects on the } \\
\text { capitals? }\end{array}$} & $\begin{array}{l}\text { Quantitative indicators concerning targets and risks and opportunities, explaining their } \\
\text { significance, their implications, and the methods and assumptions used in compiling them }\end{array}$ & PF-1 & $\begin{array}{l}\text { "target", "risk", } \\
\text { "opportunity" }\end{array}$ \\
\hline & $\begin{array}{l}\text { The organization's effects (both positive and negative) on the capitals, including material effects } \\
\text { on capitals up and down the value chain }\end{array}$ & PF-2 & "value chain." \\
\hline & $\begin{array}{l}\text { The state of key stakeholder relationships and how the organization has responded to key } \\
\text { stakeholders' legitimate needs and interests }\end{array}$ & PF-3 & "Message from BOC" \\
\hline & $\begin{array}{l}\text { The linkages between past and current performance, and between current performance and the } \\
\text { organization's outlook }\end{array}$ & PF-4 & "performance" \\
\hline $\begin{array}{l}\text { Outlook } \\
\text { What challenges } \\
\text { and uncertainties }\end{array}$ & $\begin{array}{l}\text { highlights anticipated changes over time and provide information, built on sound and transparent } \\
\text { analysis, the organization's expectations about the external environment the organization is likely } \\
\text { to face in the short, medium and long term }\end{array}$ & OL-1 & $\begin{array}{l}\text { "changes" "time" } \\
\text { "transparent" "expectation" }\end{array}$ \\
\hline $\begin{array}{l}\text { are the organization } \\
\text { likely to encounter }\end{array}$ & $\begin{array}{l}\text { highlights anticipated changes over time and provide information built on sound and transparent } \\
\text { analysis of how that will affect the organization }\end{array}$ & OL-2 & $\begin{array}{l}\text { "changes" "time" } \\
\text { "transparent" "effect" }\end{array}$ \\
\hline $\begin{array}{l}\text { in pursuing its } \\
\text { strategy, and what } \\
\text { are the potential }\end{array}$ & $\begin{array}{l}\text { highlights anticipated changes over time and provide information built on sound and transparent } \\
\text { analysis of how the organization is currently equipped to respond to the critical challenges and } \\
\text { uncertainties that are likely to arise }\end{array}$ & OL-3 & $\begin{array}{l}\text { "changes" "time" } \\
\text { "transparent" "challenge" } \\
\text { "uncertainty" }\end{array}$ \\
\hline $\begin{array}{l}\text { implications for its } \\
\text { business model and } \\
\text { future }\end{array}$ & $\begin{array}{l}\text { Discussion of the potential implications, including implications for future financial performance; } \\
\text { The external environment, and risks and opportunities, with an analysis of how these could affect } \\
\text { the achievement of strategic objectives }\end{array}$ & OL-4 & "achievement" \\
\hline performance? & $\begin{array}{l}\text { The discussion of the potential implications, including implications for future financial } \\
\text { performance, The availability, quality and affordability of capitals the organization uses or affects } \\
\text { (e.g., the continued availability of skilled labor or natural resources), including how key } \\
\text { relationships are managed and why they are essential to the organization's ability to create value } \\
\text { over time }\end{array}$ & OL-5 & "milestone" \\
\hline
\end{tabular}


Mawardani \& Harymawan

The Relationship Between Corporate Governance and Integrated Reporting

Table Appendix-C Integrated Reporting Components Disclosure Index

\begin{tabular}{lccc}
\hline Content Elements to be disclosed & Notation & $\begin{array}{c}\text { Number of } \\
\text { items }\end{array}$ & $\begin{array}{c}\text { Number of } \\
\text { Keywords }\end{array}$ \\
\hline $\begin{array}{l}\text { Organizational Overview and } \\
\text { External Environment }\end{array}$ & OR & 11 & 25 \\
Governance & GV & 7 & 16 \\
Business Model & BM & 9 & 13 \\
Risk and Opportunities & RO & 3 & 4 \\
Strategy and Resource Allocation & SR & 7 & 13 \\
Performance & PF & 4 & 6 \\
Outlook & OL & 5 & 15 \\
Integrated Reporting Disclosure & IRD & 46 & 92 \\
\hline
\end{tabular}

Table Appendix-D Integrated Reporting Disclosure Results

\begin{tabular}{ccc}
\hline SIC & 2017 & 2018 \\
\hline 0 & 11,282 words & 14,753 words \\
2 & 50,774 words & 45,945 words \\
3 & 37,926 words & 51,545 words \\
4 & 27,175 words & 34,984 words \\
5 & 40,490 words & 42,144 words \\
7 & 17,011 words & 24,277 words \\
8 & 12,192 words & 19,229 words \\
Total & 5,272 words & 5,810 words \\
\hline
\end{tabular}

\section{References}

Akhtaruddin, M., Hossain, M. A., Hossain, M., \& Yao, L. (2009). Corporate governance and voluntary disclosure in corporate annual reports of Malaysian listed firms. Journal of Applied Management Accounting Research, 7(1), 48-61. https://doi.org/10.22495/cbv8i1art4

Alvarez, R. M., \& McCaffery, E. J. (2000). Is there a gender gap in fiscal political preferences?. USC Law School, Olin Research Paper No. 00-5.

Amran, A., Lee, S. P., \& Devi, S. S. (2014). The influence of governance structure and strategic corporate social responsibility toward sustainability reporting quality. Business Strategy and the Environment, 23(4), 217-235. https://doi.org/10.1002/bse.1767

Aribi, Z. A., Alqatamin, R. M., \& Arun, T. (2018). Gender diversity on boards and forwardlooking information disclosure: evidence from Jordan. Journal of Accounting in Emerging Economies, 8(2). 205 - 222. https://doi.org/10.1108/JAEE-05-2016-0039

Barako, D. G., \& Brown, A. M. (2008). Corporate social reporting and board representation: evidence from the Kenyan banking sector. Journal of management \& governance, 12(4), 309-324. https://doi.org/10.1007/s10997-008-9053-x

Barako, D. G., Hancock, P., \& Izan, H. (2006). Factors influencing voluntary corporate disclosure by Kenyan companies. Corporate Governance: An International Review, 14(2), 107-125. https://doi.org/10.1111/j.1467-8683.2006.00491.x

Barnabè, F., Giorgino, M. C., \& Kunc, M. (2019). Visualizing and managing value creation through integrated reporting practices: a dynamic resource-based perspective. Journal 
of Management and Governance, 23(2), 537-575. https://doi.org/10.1007/s10997-01909467-z

Bear, S., Rahman, N., \& Post, C. (2010). The impact of board diversity and gender composition on corporate social responsibility and firm reputation. Journal of Business Ethics, 97(2), 207-221. https://doi.org/10.1007/s10551-010-0505-2

Burke, J. J., \& Clark, C. E. (2016). The business case for integrated reporting: Insights from leading practitioners, regulators, and academics. Business Horizons, 59(3), 273-283. http://dx.doi.org/10.1016\%2Fj.bushor.2016.01.001

Cerbioni, F., \& Parbonetti, A. (2007). Exploring the effects of corporate governance on intellectual capital disclosure: an analysis of European biotechnology companies. European Accounting Review, 16(4), 791-826. https://doi.org/10.1080/09638180701707011

De Villiers, C., Rinaldi, L., \& Unerman, J. (2014). Integrated Reporting: Insights, gaps and an agenda for future research. Accounting, Auditing \& Accountability Journal, 27(7), 10421067. https://doi.org/10.1108/aaaj-06-2014-1736

Doni, F., Larsen, M., Bianchi Martini, S., \& Corvino, A. (2019). Exploring integrated reporting in the banking industry: the multiple capitals approach. Journal of Intellectual Capital. 20(1), 165-188. https://doi.org/10.1108/jic-11-2017-0146

Du Toit, E., Van Zyl, R., \& Schütte, G. (2017). Integrated reporting by South African companies: A case study. Meditari Accountancy Research, 25(4), 654-674. https://doi.org/10.1108/medar-03-2016-0052

Eccles, R. G., \& Krzus, M. P. (2010). Integrated reporting for a sustainable strategy. New York: John Wiley \& Sons.

Eisenhardt, K. M. (1989). Agency theory: An assessment and review. Academy of management review, 14(1), 57-74. https://doi.org/10.2307/258191

Elzahar, H., \& Hussainey, K. (2012). Determinants of narrative risk disclosures in UK interim reports. The Journal of Risk Finance, 13(2),133-147. https://doi.org/10.1108/15265941211203189

Emeseh, E., \& Songi, O. (2014). CSR, human rights abuse and sustainability report accountability. International Journal of Law and Management, 56(2), 136-151. https://doi.org/10.1108/IJLMA-01-2013-0001

Falatifah, M., \& Hermawan, A. A. (2018). Board of directors effectiveness, audit committee effectiveness, and cost of equity: Role of voluntary integrated reporting. Proceedings of the 32nd International Business Information Management Association Conference, IBIMA 2018 - Vision 2020. Retrieved from https://scholar.ui.ac.id/en/publications/board-ofdirectors-effectiveness-audit-committee-effectiveness-an

Fama, E. F., \& Jensen, M. C. (1983). Separation of ownership and control. The Journal of Law and Economics, 26(2), 301-325. https://doi.org/10.1086/467037

Fasan, M., \& Mio, C. (2017). Fostering stakeholder engagement: the role of materiality disclosure in integrated reporting. Business Strategy and the Environment, 26(3), 288-305. https://doi.org/10.1002/bse.1917

Gamerschlag, R., Möller, K., \& Verbeeten, F. (2011). Determinants of voluntary CSR disclosure: Empirical evidence from Germany. Review of Managerial Science, 5(2-3), 233-262. https://doi.org/10.1007/s11846-010-0052-3

Garcia-Meca, E., \& Sanchez-Ballesta, J. P. (2010). The association of board independence and ownership concentration with voluntary disclosure: A meta-analysis. European Accounting Review, 19(3), 603-627. https://doi.org/10.1080/09638180.2010.496979

Ghani, E. K., Jamal, J., Puspitasari, E., \& Gunardi, A. (2018). Factors influencing integrated reporting practices among Malaysian public listed real property companies: A 
sustainable development effort. International Journal of Managerial and Financial Accounting, 10(2), 144-162. https://doi.org/10.1504/ijmfa.2018.091662

Gray, R., Kouhy, R., \& Lavers, S. (1995). Corporate social and environmental reporting: a review of the literature and a longitudinal study of UK disclosure. Accounting, Auditing \& Accountability Journal, 8(2), 47-77. https://doi.org/10.1108/09513579510146996

Hill, C. W., \& Jones, T. M. (1992). Stakeholder agency theory. Journal of Management Studies, 29(2), 131-154. https://doi.org/10.1111/j.1467-6486.1992.tb00657.x

Ho, S. S., \& Wong, K. S. (2001). A study of corporate disclosure practice and effectiveness in Hong Kong. Journal of International Financial Management \& Accounting, 12(1), 75-102. https://doi.org/10.1111/1467-646X.00067

Hossain, M., Perera, M. H. B., \& Rahman, A. R. (1995). Voluntary disclosure in the annual reports of New Zealand companies. Journal of International Financial Management \& Accounting, 6(1), 69-87.

Hossain, M., Tan, L. M., \& Adams, M. (1994). Voluntary disclosure in an emerging capital market: Some empirical evidence from companies listed on the Kuala Lumpur Stock Exchange. The International Journal of Accounting, 29, 334-351. Retrieved from https://www.econbiz.de/Record/voluntary-disclosure-in-an-emerging-capitalmarket-some-empirical-evidence-from-companies-listed-on-the-kuala-lumpur-stockexchange-hossain-mahmud/10006637938

Huang, P., \& Zhang, Y. (2011). Does enhanced disclosure really reduce agency costs? Evidence from the diversion of corporate resources. The Accounting Review, 87(1), 199-229. https://doi.org/10.2308/accr-10160

IIRC. (2013). The International Integrated Reporting Framework. Retrieved from https://integratedreporting.org/resource/international-ir-framework/

Inchausti, B. G. (1997). The influence of company characteristics and accounting regulation on information disclosed by Spanish firms. European Accounting Review, 6(1), 45-68. https://doi.org/10.1080/096381897336863

Ito, K., \& Iijima, M. (2017). Integrated reporting and its impact on organisational change. International Journal of Human Resources Development and Management, 17(1-2), 73-88. https://doi.org/10.1504/ijhrdm.2017.085262

Jensen, M. C., \& Meckling, W. H. (1976). Theory of the firm: Managerial behavior, agency costs and ownership structure. Journal of Financial Economics, 3(4), 305-360. https://doi.org/10.1016/0304-405X(76)90026-X

Jizi, M. I., Salama, A., Dixon, R., \& Stratling, R. (2014). Corporate governance and corporate social responsibility disclosure: Evidence from the US banking sector. Journal of Business Ethics, 125(4), 601-615. https://doi.org/10.1007/s10551-013-1929-2

Kılıç, M., \& Kuzey, C. (2018a). Assessing current company reports according to the IIRC integrated reporting framework. Meditari Accountancy Research, 26(2), 305-333. https://doi.org/10.1108/medar-04-2017-0138

Kılıç, M., \& Kuzey, C. (2018b). Determinants of forward-looking disclosures in integrated reporting. Managerial Auditing Journal, 33(1), 115-144. https://doi.org/10.1108/maj-12-2016-1498

Krishnan, G. V., \& Parsons, L. M. (2008). Getting to the bottom line: An exploration of gender and earnings quality. Journal of Business Etbics, 78(1-2), 65-76. https://doi.org/10.1007/s10551-006-9314-z

Krzus, M. P. (2011). Integrated reporting: if not now, when?. Zeitschrift für Internationale Rechnungslegung, 6(6), 271-276. Retrieved from https://scholar.google.com/scholar?q=Krzus, \%20M.P.\%20.\%20Integrated $\% 20$ rep 
orting: $\% 20$ if $\% 20$ not $\% 20$ now, $\% 20$ when $\% 20$ Zeitschrift $\% 20$ fuer $\% 20$ Internationale $\%$ 20Rechnungslegung, $\% 20271-276$.

Lee, K. W., \& Yeo, G. H. H. (2016). The association between integrated reporting and firm valuation. Review of Quantitative Finance and Accounting, 47(4), 1221-1250. https://doi.org/10.1007/s11156-015-0536-y

Manita, R., Bruna, M. G., Dang, R., \& Houanti, L. H. (2018). Board gender diversity and ESG disclosure: evidence from the USA. Journal of Applied Accounting Research, 19(2), 206 to 224. https://doi.org/10.1108/jaar-01-2017-0024

Michelon, G., \& Parbonetti, A. (2012). The effect of corporate governance on sustainability disclosure. Journal of management \& governance, 16(3), 477-509. https://doi.org/10.1007/s10997-010-9160-3

Mitnick, B. M. (1992). The theory of agency and organizational analysis. The Ruffin Series in Business Ethics, 75-96.

Nakib, M., \& Dey, P. K. (2018). The journey towards integrated reporting in Bangladesh. Asian Economic and Financial Review, 8(7), 894-913. https://doi.org/10.18488/journal.aefr.2018.87.894.913

Nalikka, A. (2009). Impact of gender diversity on voluntary disclosure in annual reports. Accounting \& Taxation, 1(1), 101-113. Retrieved from https://ssrn.com/abstract $=1555069$

Nazli Nik Ahmad, N., \& Sulaiman, M. (2004). Environment disclosure in Malaysia annual reports: A legitimacy theory perspective. International Journal of Commerce and Management, 14(1), 44-58. https://doi.org/10.1108/10569210480000173

Ofoegbu, G. N., Odoemelam, N., \& Okafor, R. G. (2018). Corporate board characteristics and environmental disclosure quantity: Evidence from South Africa (integrated reporting) and Nigeria (traditional reporting). Cogent Business and Management, 5(1), 1-27. https://doi.org/10.1080/23311975.2018.1551510

Owusu-Ansah, S. (1998). The impact of corporate attribites on the extent of mandatory disclosure and reporting by listed companies in Zimbabwe. The International Journal of Accounting, 33(5), 605-631. https://doi.org/10.1016/s00207063(98)90015-2

Patelli, L., \& Prencipe, A. (2007). The relationship between voluntary disclosure and independent directors in the presence of a dominant shareholder. European Accounting Review, 16(1), 5-33. https://doi.org/10.1080/09638180701265820

Pavlopoulos, A., Magnis, C., \& Iatridis, G. E. (2017). Integrated reporting: Is it the last piece of the accounting disclosure puzzle? Journal of Multinational Financial Management, 41, 23-46. https://doi.org/10.1016/i.mulfin.2017.05.001

Pavlopoulos, A., Magnis, C., \& Iatridis, G. E. (2019). Integrated reporting: An accounting disclosure tool for high quality financial reporting. Research in International Business and Finance, 49, 13-40. https://doi.org/10.1016/j.ribaf.2019.02.007

Pratama, A. (2017). Clustering Indonesian companies' Annual Reports: Preliminary assessment of the implementation of integrated reporting by Indonesian listed companies. International Journal of Globalisation and Small Business, 9(1), 46-54. https://doi.org/10.1504/iigsb.2017.084697

Roxana-Ioana, B., \& Petru, S. (2017). Integrated reporting for a good corporate governance. Ovidius University Annals, 17(1), 424-428.

Shanti, Tjahjadi, B., \& Narsa, I. (2018). The effect of integrating reporting on earnings quality: A study of family firms in Indonesia. J. Fin. Bank. Review 3(3) 34-40. Retrieved from https://ssrn.com/abstract $=3273901$ 
Shapiro, S. P. (2005). Agency theory. Annu. Rev. Sociol., 31, 263-284. Retrieved from https://www.annualreviews.org/doi/abs/10.1146/annurev.soc.31.041304.122159

Sofian, I., \& Dumitru, M. (2017). The compliance of the integrated reports issued by European financial companies with the international integrated reporting framework. Sustainability, 9(8), 13-19. https://doi.org/10.3390/su9081319

Soliman, M. (2013). Firm characteristics and the extent of voluntary disclosure: The case of Egypt. Research Journal of Finance and Accounting, 4(17), 1-20. https://doi.org/10.2139/ssrn.2311005

Srinidhi, B., Gul, F. A., \& Tsui, J. (2011). Female directors and earnings quality. Contemporary Accounting Research, 28(5), 1610-1644. https://doi.org/10.1111/j.1911$\underline{3846.2011 .01071 . \mathrm{x}}$

Suchman, M. C. (1995). Managing legitimacy: Strategic and institutional approaches. Academy of Management Review, 20(3), 571-610. https://doi.org/10.5465/amr.1995.9508080331

Sun, J., Liu, G., \& Lan, G. (2011). Does female directorship on independent audit committees constrain earnings management?. Journal of Business Ethics, 99(3), 369382. https://doi.org/10.1007/s10551-010-0657-0

Suttipun, M., \& Bomlai, A. (2019). The relationship between corpoarat governance and integrated reporting: Thai evidence. International Journal of Business and Society, 20(1), 348-364. Retrieved from http://www.ijbs.unimas.my/index.php/contentabstract/all-issues/65-vol-20-no-1-2019/568-the-relationship-between-corpoaratgovernance-and-integrated-reporting-thai-evidence

Wang, M., \& Hussainey, K. (2013). Voluntary forward-looking statements driven by corporate governance and their value relevance. Journal of Accounting and Public Policy, 32(3), 26-49. https://doi.org/10.1016/i.jaccpubpol.2013.02.009

Zyznarska-Dworczak, B. (2018). Legitimacy Theory in Management Accounting Research. Problemy Zarzadzania, 16(72), 195-203. https://doi.org/10.7172/1644$\underline{9584.72 .12}$ 